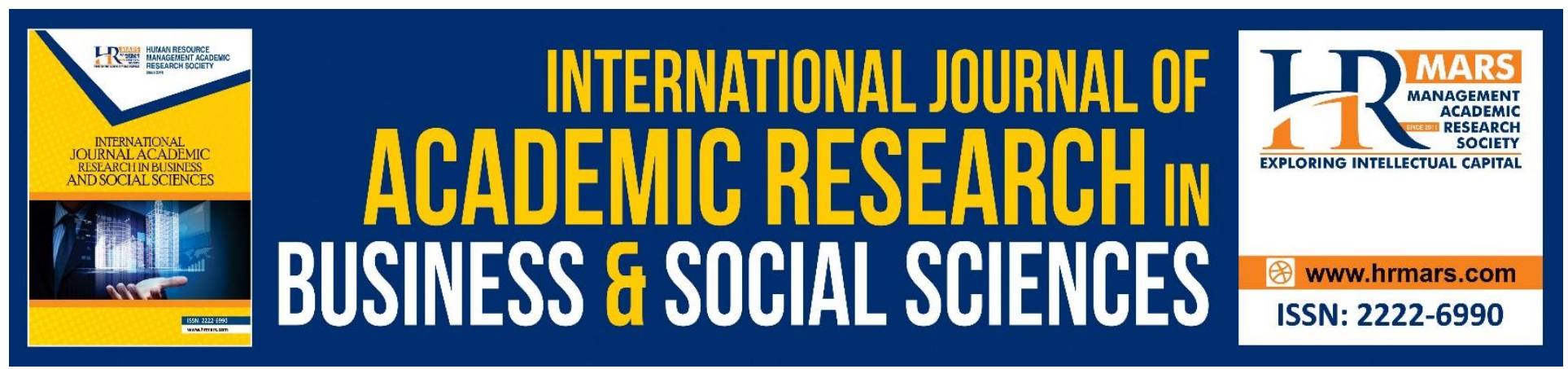

\title{
Way of Life of Thais in Germany
}

\section{Dusadee Ayuwat and Orathai Piayura}

To Link this Article: http://dx.doi.org/10.6007/IJARBSS/v10-i14/7694

DOI:10.6007/IJARBSS/v10-i14/7694

Received: 09 April 2020, Revised: 11 May 2020, Accepted: 22 June 2020

Published Online: 25 July 2020

In-Text Citation: (Ayuwat \& Piayura, 2020)

To Cite this Article: Ayuwat, D., \& Piayura, O. (2020). Way of Life of Thais in Germany. International Journal of Academic Research in Business and Social Sciences, 10(14), 258-269.

\section{Copyright: @ 2020 The Author(s)}

Published by Human Resource Management Academic Research Society (www.hrmars.com)

This article is published under the Creative Commons Attribution (CC BY 4.0) license. Anyone may reproduce, distribute, translate and create derivative works of this article (for both commercial and non-commercial purposes), subject to full attribution to the original publication and authors. The full terms of this license may be seen

at: http://creativecommons.org/licences/by/4.0/legalcode

Special Issue: WSTI2018 - Issues and Trends on Education, Science and Technology, 2020, Pg. 258 - 269

Full Terms \& Conditions of access and use can be found at http://hrmars.com/index.php/pages/detail/publication-ethics 


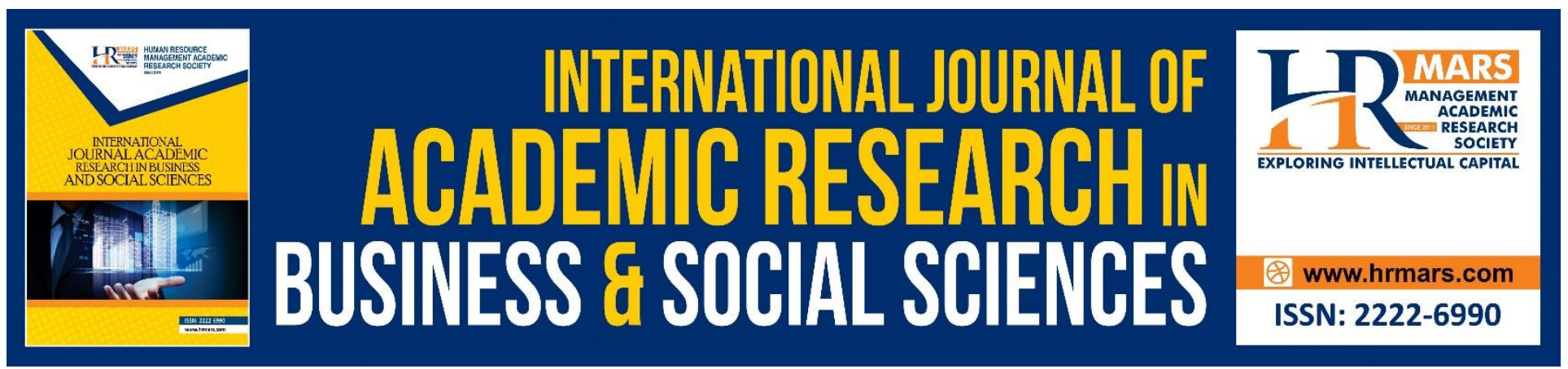

\title{
Way of Life of Thais in Germany
}

\author{
Dusadee Ayuwat ${ }^{1}$ and Orathai Piayura ${ }^{2}$ \\ ${ }^{1}$ Department of Social Sciences, Division of Sociology and Anthropology, Labour and International \\ Migration Service Center, ${ }^{2}$ Department of Thai Language, Faculty of Humanities and Social Sciences \\ Khon Kaen University, Khon Kaen, Thailand \\ Email: ${ }^{1}$ dusayu@kku.ac.th
}

\begin{abstract}
This article examines the way of life of Thais in Germany. The qualitative approach was applied for data collection in June 2018 by in-depth interview and observation. Data were analyzed by the content analysis method. The results found that the way of life of the Thai family in Germany comprised of 3 dimensions 1) Economics dimension: they own the shops (massage shop, karaoke, and restaurant) and work as labour. 2) Social and Cultural dimension: they have networks (sharing information about rights and sources of working) and they practice the Thai cultures to maintain Thainess.
\end{abstract}

Keywords: lifestyle, Thai Community in Germany, Thainess

\section{Background and Significance}

Migration is a phenomenon that arises from the socio-economic differences between the place of origin and destination. It is also a strategy used by migrants to seek better life chances. Migration abroad begins from the moving of highly skillful people to work in developed countries or those who went to study abroad and ended up getting married and settled down in countries in Europe or the US. This led to settlement of Thai people in foreign countries. Surveys by Thai embassies and Thai Consulates abroad show as high as 1,001,070 Thai people living in every region of the world, 66,000 in the US, over 56,000 in Germany, 15,000 in Switzerland, 9,500 in Denmark and 6,800 in Finland (Department of Consular Affairs, Ministry of Foreign Affairs, 2016). Living in a foreign country especially Germany where cultural and socio-economic conditions differ necessitates Thai people to adjust themselves in order to live happily there. This article is written from the interest to study Thai people's lifestyle in Germany which is related to the social structure, Thai people's roles, and Thai communities. The results include a body of knowledge of Thai people's lifestyles in a foreign country under the current complex migration situation. In addition, the knowledge of Thainess at the destination place that is formed from the lifestyle of Thai migrating people is obtained.

\section{Research Objectives}

To study the lifestyles of Thai people in Germany. 


\section{Related Documents and Research Studies}

Lifestyle concepts: Lifestyle means the ways of living of people in the society demonstrated though their activities and are related to an individual who interacts with his or her surroundings (Kotler, 2000). There is the relation of this with valuing, personality and personal traits (Mowen \& Minor, 1998). One's lifestyle is expressed by the characteristics and behaviors of the person. In general, the lifestyle of people in groups depends on the rules observed by the members of the group. The behaviors of the members in a group are similar. Besides, the economic, social, and cultural classes also determine the lifestyles of the people in the society (Onkvisit \& Shaw, 1994). Engel, Blackwell \& Miniard (2003) added that a person's lifestyle is reflected by his or her activities, interests, and opinions; all of which are related to personality and social class, which in turn, may determine a person's lifestyle in the society. In this research, lifestyle is defined as the ways of living of Thai people in Germany that are reflected through their activities, interests, and opinions in the economic, social, and cultural dimensions, which are the results of their social backgrounds.

Migration concepts: Lee's definition (1996) states that migration is the change of permanent or temporary accommodation without any limitations on the moving distance or the willingness or unwillingness of the migrating person. The Population Reference Bureau of Washington (2014) defines migration as the moving of population across a nation's boundary with an aim to find a new abode. Some scholars explain that migration means the moving of a great number of population from their original abodes to another place in order to perform an activity that yields remuneration, which is the main reason for such migration. All of these agree with the belief of Ravenstein (1885), who explained that the economic, social and environment situations are the factors behind migration. Migration is the process that arises because of the need to upgrade economic status, and hence it is principally from an under-developed area to a better developed area. For most of the cases, migration is performed through a process of independent decision towards a better life of the migrant or the family (IOM, 2004).

Migration of women, in particular, is done for employment and for marriage with a foreigner. A cross-cultural family is thus established at the destination. Sassen (2000) explained the reasons for the cross-cultural marriage in an article named, "Women's Burden: Counter-geographies of Globalization and the Feminization of Survival". In this article, migration either for marriage or for employment in a foreign country is done through selection of a country of a greater level of development than the origin country. Therefore, the women in this group choose to work or marry and live with a husband in a richer country and leave their home country for a better living. It should be noted that in many cases, the living condition and social status of the women at their origin country are better than at the destination. However, there are still a lot of women who are not successful in their lives at the destination country (Oxfeld \& Suzuki, 2005). The researcher therefore considered the lifestyles of Thai people in a foreign country based on the concepts of migration and migration situations, which are associated with marriage with a foreigner, employment, and participation in Thai people's activities.

\section{Research Methodology}

The Qualitative Methodology was applied with the Phenomenology approach since it was necessary to explain the lifestyles of Thai people living in Germany where the number of Thai people is one among those at the top list in Europe. The analytical unit was at a group level. In order to obtain diverse information, 18 informants living in big cities were involved including 3 Thai women who were 
married to Germans, 5 Thai workers working in Germany, 1 Thai woman who married to a Thai man and settle down in Germany, 3 owners (both male and female) of restaurants and accommodation, 1 Thai student, 1 representative of a governmental organization, 2 representatives of independent foreigner-assisting organizations, 1 monk and 1 member of a European Thai Women network. The data was collected through the in-depth interview for clear and profound information (Pothisita, 2004). Non-participatory observation was also conducted during the interview which was performed from June to July, 2018. The data was analyzed based on the descriptive analysis method for a clear picture of Thai people's lifestyles in Germany.

\section{Research Results}

The research results are presented in 2 categories: 1 ) Thai families in Germany and 2) the lifestyles of Thai people living in Germany, as follows:

Cross-cultural families (Thai-German) - Thai people living in Germany have diversified living patterns according to the length of stay and characteristics, namely, age, education level, marriage status, and occupation. The researcher classified Thai people families in Germany into the following 5 groups:

\section{Well-off Thai women families}

This group comprises Thai women aged older than 50 years, holding at least a bachelor's degree and married to a German of similarly high education. Thus, the women have visa from their marriage. Their husbands are the head of the family and hold occupations in an academic field or head of a department. The Thai women are housewives or independent academicians. This type of family has good social and economic status from the high incomes from their permanent work. They are known in the academic and social circles and take their roles as helpers of Thai people in Germany. The Thai women in this group were married and moved to German over 30 years ago. They have mixed-race children that could be 30 years old of age. The children receive high education and hold a secure occupation similar to their parents. The family of this type takes very good care of their children since childhood until at the present time. The Thai women communicate with their children both in Thai and German. In addition, the German husband attempt to learn Thai language. They also help with household chores such as house cleaning, cooking, washing, etc.

\section{Families of Thai entrepreneurs in Germany}

Thai people in this group consist of both men and women who married German people and have lived in Germany for a long time, although most of them are women aged 35 years and older. This group completed secondary school up to university level. They are skillful in cooking and management. Some used to work as a chef in Thailand before migrating to work in a restaurant in Germany and got married to a German. Thai women in this group have been married to a German for a long time and have children with the German. They raise up their children in a western cultural style since the family live in Germany. The children go to Germany school and could be influenced by their German friends and the surrounding, and therefore do not communicate with their mothers in Thai. Many of these mixed-race children do not like Thai food, necessitating their mothers to learn to cook western foods. 


\section{Families of Thai women of moderate income}

This group comprises women aged 35 years and older. Most completed primary or secondary school. Their former occupation was farming or being workers in enterprises. The average marriage period with German husbands was roughly 15 years. They were introduced to German men by a female friend who was married to a German for a long time. This group has been granted visa for marriage with a German and can stay in Germany. Some couples have mixed-race Thai-German children, who are now adolescents. This type of family raises their children in a western style, giving their children freedom in terms of university program. Some marriage couples still live in the family of the German husbands with the husbands' parents. This prevents the Thai women to teach their children Thai and Thai culture, and thus the children cannot speak Thai. However, they understand their mothers' talking to them in Thai. In some families, the women married to a German husband after divorce from their Thai husband. They now live with and rely on the German husband and thus do not want to demonstrate Thai culture. These families therefore do not teach their children Thai language. It was also found that in this type of family, the German husband is the head of the family and earns the major income. The Thai women are housewives and take care of the family members. Because the incomes of this type of family are not high, some wives work part time outside in a type of non-formal job and receive low income. The work of the women in this group is therefore only supplementary to their family with a portion remitted back home in Thailand.

\section{Thai women with no life security}

Most of the women in this group, who are from 35 years old and over, formerly worked as an employee or worker in a restaurant in Thailand or used to be in a farming household. They completed elementary or secondary education. Some were married to German men and divorced many times. It can be said that they are not successful in terms of family. Their background is a constraint when they look for a job. The women in this group do not have children with their German husband, thus live an insecure life. They did not spend much time to study their partner before marriage because they were introduced through acquaintances (Ayuwat, Mee-Udon, \& Grisanaputi, 2012) or met at the working place. After studying each other for a while, the women moved to German as a German spouse. However, to marry a German, a Thai woman is required to pass a certain criterion of German language test in order to guarantee the living in German. The length of time of living with the husband of this group of women is 1-10 years before divorce. After the divorce, they become friend with other German men in order to find security in their life. The women need to continue to struggle in the western society since they are still not successful. They also have to earn the living and send money to the family at the origin.

\section{Thai families abroad (Whole Thai family)}

Thai people in this group were married to Thai people and moved to Germany 20-30 years ago. They were 45 years old and over, graduated from a high school or a university. They are granted German visa because of their length of stay. The Thais in this group are skillful in Thai culinary or other services. They were married before or after moving to Germany, have children together, raise their children using the western cultures from birth in terms of language, food, lifestyle and friends. They believe that as they are to live in Germany, if they raise their children following Thai culture, their children will have difficulties in socialization. It can be seen that the worries of these Thais stop their children from learning Thai language. The family therefore communicates in German. Presently 
this group hold occupations as entrepreneurs and employ Thai, Vietnamese or other Asian people in their businesses, most of which are in the service line.

Diversities are thus obvious of Thai families in Germany. These cover the family foundation in Thailand before migration to Germany. The differences reveal their chances to develop themselves before entering their occupation. Diversities are also reflected by communication in family, and Thai culture adopted of each type of family. The status of Thai women living abroad status also influences their Thai culture dissemination, especially when the women depend on their foreign husband; demonstrating Thai culture or use of Thai language is a constraint in this respect. These are consistent with the study by Ebbeler, Grau, \& Banse, (2017), who explained that women in a cross-cultural family do not dare to express their local culture, or sub-culture within the society where major cultures dominate.

\section{Lifestyle of Thai people in Germany}

From the living patterns of cross-cultural Thai families - those married to German people and Thais married together and live there - it is seen that different patterns reflect different their economic, social, and cultural lifestyles based on the social status or security in various aspects of life. The following part discusses the lifestyles of Thai people in a foreign country classified into 2 dimensions, which have been analyzed with the characteristics of Thai people in Germany.

\section{Lifestyle in terms of economy: Occupation determines life path}

Thai families living in Germany have diversified economic lifestyles according to the family status. Thus, their occupation, expenditure, and savings differ. Explanation below is based on their living in the household and their lives in public places:

1.1. Lifestyle in the household - Thai women living in a cross-cultural family are housewives who take care of the household, for example, cleaning, cooking, looking after children and family members, and shopping grocery. Their German husbands are the family head who earn the living. This cross-cultural household pattern reflects that men lead the family and take more economic role, and is especially true with the medium-income family where Thai women are fully responsible of the household. However, some Thai women still work part time and receive payment on an hourly basis in order to avoid taxation of formal employment in the country (Thai Embassy in Berlin, 2014).

Nevertheless, Thai women who are not successful in terms of family and who live alone live their lives in a laissez-faire style, i.e., not caring about neatness and not interested in other people because they live alone. These Thai women take care of themselves and see the importance of jobs in order to earn their living.

1.2. Lifestyle in public places - Lifestyles in public places of cross-cultural families are related to their occupation since occupation determines the family's economic lifestyles. The occupations of Thai women in this regard can be classified into 3 groups:

1) Officers of governmental or private organizations - This group comprises Thai people who hold a bachelor's degree or higher. They possess academic skills and language proficiency. They are employed in an economic high-security job, such as head of department in a company, an academic job in an institute or in a local governmental organization. Therefore, they earn a regular income and 
are entitled to official fringe benefits. The office hours of the Thais in this group are fixed, with holidays and vacations when they can take their family to a trip upcountry or to a foreign country. Thai women who are well-off are in this cross-cultural family. Both the women and the husbands have secure jobs and have their own house. The house may be inherited from the family of the German husband or a new house constructed from their own savings. They also have savings and are entitled to governmental welfare. It can be said that the economic security of this type of family is at a high level, which results from the occupation security and regular incomes from the jobs of the husband and from children. They have purchasing power to buy things they want, and have established savings from insurance for the future security.

2) Independent occupation/ owners of service enterprises - This group comprises Thai people whose education background is from secondary school up to doctorate degree level. They have management skills, culinary skills, and language competency from their long-stay in the country. Many started from being an employee in a business enterprise, then got married to a German and thus obtained visa to live in the country as well as the right to establish a business such as Thai restaurant or hostel. Thai restaurant entrepreneurs had to accumulate economic capitals including monetary and accommodation before starting their business which requires a great amount of money, for example, shop decoration, labor wages, goods, raw materials and entrepreneurial tax. After the shop is established and known, there are regular customers that bring more and more profits. At present, some shops employ Thai or Vietnamese laborers to help as the wages of these laborers are not high. These hired workers understand the tastes of food and Asian characteristics, and hence are suitable to work here. Thai people in this group have a high level of economic security from continuous income. They are free to spend money or relax upcountry and abroad without problems.

In addition, some Thai people own a small-scale business such as a massage shop. These Thais completed secondary school from home but are skillful in Thai traditional massaging from their previous occupation. After getting married to a German husband, they opened a small business and gradually have regular customers who come for relaxing massage to relieve tension from hard work. However, although they have their own business, the business is still small with limited customers. These women therefore have constraints behind their expenditure. The income and the expenditure are just equal. This means not much savings. Their lives are therefore confined to the accommodation place with no leisure trips away from home. The lifestyle is economized with attempts to accumulate more economic capital.

3) Employees of service enterprises, clerical officers and elderly caregivers Thai women in this group work on an hourly basis. Their education level is from elementary to secondary. The group is composed of married and separate or divorced Thai women who have to struggle to live. Those married and live together have the husband to earn the main income while the women work part time as an employee at a restaurant, a massage shop, or work as a stock checker or an elderly caregiver. The money earned supplements the major income and is remitted home. Some Thai women work under the time limitation since the law that governs taxation states a certain amount of income requiring tax. Therefore, employment of these women shows their strategy to struggle to live (De Jong et al., 2002). Some Thai women set up a 'share' group among their friends as a strategy 
to save money in case of emergency. It is observed that Thai people in this group economize in every way such as growing garden vegetables in order to reduce expense.

As for the women who were married and separate or divorced, they have to struggle to earn income for their living and for remittance money to the family or children in Thailand. These women were married in Thailand and already divorced. Some are employed at a restaurant, massage shop, beauty dresser; while some are elderly caregiver, which are jobs that do not require skills since their human capital, occupational skills, or educational level are still low (DFID, 1999). Those who have children from the divorced German husband do not let their children work so that the children can receive money allowance as an unemployed. The children can work illegally such as copying CD, VCD, DVD and selling to friends. This group may borrow money from Thai friends for daily expense. Some fail to pay back in time. Thus, this group is seen as an economic fragile group because they have to struggle to live and have constraints in earning and spending money.

\section{Socio-cultural lifestyle: family, community and social group: Interaction areas and Thainess}

The socio-cultural lifestyles of Thai people families living in Germany are associated with the interactions of family members and the social groups in Germany. The two following areas of their lifestyles are as follows:

2.1. Household area: Roles and household discipline - The socio-cultural lifestyles in the household of cross-cultural families are associated with the members' roles and duties in the household, which include marriage couple's roles and father's and mother's roles. Different types of families place importance to different roles. As a whole, women are given the roles of housewife who manage the orderliness in the house. Women are still "the back-feet elephant" (the follower) while men take the role of the family leader. Another important role of women is taking care of the children. The family of a well-off woman raises the children in two cultures, western and Thai. The husband and children also assist in some household chores, which is one way to discipline the family members to be considerate toward one another. The women in moderate-income families, on the other hand, have limitations in raising up children in an integrated cultural surrounding. Some do not have a chance to teach their children to speak Thai and scarcely cook Thai food for their children since they live with the husband's father and mother (Hareven, 2018), who certainly want their grandchildren to be German and have a western lifestyle. The Thai women who live with them and take the role of a wife and a daughter-in-law are thus courteous and cannot instill Thainess among their children.

However, Thai people families in a foreign country raise their children according to the western culture, and intensively train their children to use western culture because they want the children to be competent in German language, receive high education, and know a lot of people. They do this by speaking to their children in German, adopt German lifestyle, avoid Thai language in the family, and do not cook Thai food for the children. The intention to make their children understand and live their lives as a German results in the children not speaking Thai, not eating Thai food until some do not want to reveal to others that they are Thais. This reflects cultural assimilation where Thai people are assimilated from the former culture until Thainess is totally absent (Bureau of National Cultural Committee, 2007). 
2.2. Public area: Thai people community and Thai cultural dissemination - The following part explains social interactions of Thai people and dissemination of Thai culture in two public areas:

1) Activities at Thai people communities - The lifestyle of cross-cultural families requires interaction with the neighbors and other Thais in order to build a social network or to strengthen it. The moderate-income Thai women, in particular, hold regular activities to enhance relationship. They use a special occasion of their family members to have social gatherings with the German and Thai neighbors, for example, a family member's birthday, anniversary, ordaining, etc. This is the use of the area to join together, talk together, share their experiences, showing empathy towards one another. These activities lead to mutual assistance and sharing of foods and items depending on the case; reflecting overseas Thai community where patronage or assistance still dominate. However, clustering of Thai women may not be appreciated by their German husbands since in general the western society sees the importance of privacy. Thai migrating women, on the contrary, like to relax and entertain themselves and thus join together whenever they have a chance. The German husbands do not prevent their wives from joining their friends, for they understand that it is their wives' happiness. This also shows good understanding between successful couples (Preedapan \& Ayuwat, 2017).

In addition, Thai academics are often tied to formality, and hence are more familiar with people in academic circles more than other groups. For example, some are members of a network group or a member of an organization. These women are involved in regular meetings and take responsibilities in assisting and protecting Thai people who are being in trouble. With their academic and language skills, these families are seen as hard to contact and do not interact much with Thai women or Thai people in other groups. Nevertheless, when there are merit making events or rituals of Thai people, this group generally joins. What is said about this group is also true with the restaurant entrepreneurial group who usually join in important occasions as they see their business as the priority. The latter has also built a network with Thai and Vietnamese laborers for their business.

2) Activities in Thai temple - The socio-cultural lifestyles of Thai people living in Germany are also associated with Thai temple since a Thai temple is a socio-cultural area that reflects Thainess. During religious and traditional occasions, there are a number of activities and merit making events at Thai temples, for examples, paying respect to the elderly, speaking in Thai, cooking and eating Thai food, wearing Thai sarongs, wearing silk, performing Thai rituals, building Thai atmosphere at a place where such manifestation is not restricted. In general, Thai people take their family members to join the events. The scheduling of each event is flexible so that all groups of Thai people are able to join. For instance, Songkran festival in Thailand is held in the middle of April, whereas in Germany the festival can be delayed until later when everyone is available and the occasion will suit the foreign country's context. There is an exception for Kathin ceremony, which is strictly scheduled. Thai people from various groups join such important events via formal and informal invitation. Events that are held at Thai temples have the atmosphere of Thai and reflect Thainess even though they are held overseas. Thai people still hold the sense of being Thai, and a Thai temple is the center where they can meet and organize Thai activities. The temple enables Thai people to be aware of Dhamma and conduct themselves accordingly with calm mind. It is the place that Thai Buddhists repose their trust in. 
3) Thai culture dissemination - In general, Thai people in Germany live harmoniously with German people, but they do not discard or forget Thai culture. They particularly disseminate Thai cultures in the family through social assimilation. Dissemination of culture at a public place is another interesting point, especially the public relation of Thai community events, which is usually done at a vast scale, nearly similar to a tourism activity. Thai culture is then publicized among foreigners. Another Thai group that disseminates Thai culture is the Thai restaurant entrepreneurs, accommodation business runners, and Thai massage business. The business venues are decorated with many items and symbols demonstrating Thainess, from the shop name that reflects Thai identity known by foreigners to enhance perception of Thai food, tourism in Thailand, to pictures of the Royal family, Buddha icons, famous senior monks, Thai arts, Thai classical music, Thai crockery, Thai food menus, and Thai food tastes which are spicy and reflect Thainess. The articles of clothing of shop assistants, performances in the shop such as Thai dance or music all demonstrate clear Thai identity. All of these reflect Thailand among the foreigners and truly publicize Thai culture abroad. It can be seen that Thai people's lifestyles in Germany have been proceeding through the economic dimension, i.e., occupations as well as socio-cultural dimension, i.e., social assimilation, at the key areas of household and public places. These reflect the ways of living of Thai people in Germany and variedly demonstrate Thainess that occurs in a foreign country.

\section{Conclusion and Recommendations}

The lifestyles of Thai people living in Germany can be said to vary, including economic lifestyles dictated by educational levels, occupations, and income that determine one's life path both at the household and public places. The socio-cultural lifestyles of Thai people are connected to family interaction and the public places that reflect Thainess through activities. The group that should be noted is the Thai women group who married to a German husband who is still not economically stable and hence their lives are not secure. This group of women still struggle to earn their living and remit money back home where members are still in trouble in terms of economy, social and culture. Thus, relevant organizations, for example, Thai women network in Europe, Thai Embassies, Department of Consular Affairs, Department of Women Affairs, and Family Institute should pay attention to these problems and set measures for solution or mitigation of the troubles of those living abroad such as establishing a mechanism for access of employment. Besides, criteria should be established for those migrating abroad to have accurate knowledge and understanding of the situations. In addition, measures should be set to enhance Thainess demonstration within the migrants' household and public places.

\section{Acknowledgments}

This article uses the information from the research study on the role of Thai people networks and the establishment of Thainess in a foreign country, which received monetary support from Faculty of Humanities and Social Sciences of Khon Kaen University. The research team is grateful to the Faculty's administrators who see the importance of research work and supported the study. Thanks are extended to all of the Thai women who were married to Germans, Thai workers working in Germany, representative of a governmental organization, and member of a European Thai Women network who helped provide the useful information for this research. 


\section{References}

Ayuwat, D., Mee-Udon, F., \& Gritsanaputi, W. (2011). Final Report of Program for the prevention and protection of Thai women working abroad. Khon Kaen: Faculty of Humanities and Social Sciences, Khon Kaen University.

Ayuwat, D., Mee-Udon, F., \& Grisanaputi, W. (2012). Cross-cultural Marriage of rural women in Northeast Thailand: Love or Gender Culture? Net Global Conference (2012, September 25-27). United Kingdom: Mansfield College, Oxford.

Bureau of National Cultural Committee. (2011). The new face of culture and development. Bangkok: Bureau of National Cultural Committee, Ministry of Education.

Deemanop, M. (2003). Lifestyle of Thai Women. Khon Kaen: Bureau of Economic and Social Development the North East.

DFID. (1999). Sustainable Livelihoods Guidance Sheets. London: Department for International Development (DFID).

Ebbeler, C., Grau, I., \& Banse, R. (2017). Cultural and Individual Factors Determine Physical Aggression Between Married Partners: Evidence From 34 Countries. Journal of Cross-Cultural Psychology, 27(3), 143-157.

Engel, J. F., Blackwell, R. D., \& Miniard, W. P. (2003). Consumer behavior. Chicago: Dryden Press. European Thai Women network. (2018, September 10). History and Background. Retrieved from https://twne.eu/

International Organization for Migration (IOM). (2004). International Migration Law: Glossary on Migration. Geneva: International Organization for Migration.

Jong, D., Gordon, Chamrarrirthirong, A., \& Tran, Q. G. (2002). For better, for worse: life satisfaction consequences of migration, International Migration Review, 36, 3: 838-63.

Kotler, P. (2000). Marketing management: Analyzing consumer marketing and Buyer behavior (The Millennium). New Jersey: Prentice Hall.

Lee, E. S. (1996). A Theory of Migration. Demography, 3(1), 47-57.

Mowen, J. C., \& Minor, M. (1998). Consumer Behavior. Upper Saddle River: Prentice-Hall, Inc.

National Statistics Organization. (2010). Summary of Population Performance Survey 4 quarter. Bangkok: National Statistics Organization, Bureau of President.

Onkvisit, S., \& Shaw, J. (1994). Consumer Behavior: Strategy and Analysis. Macmillan College Publishing Company.

Oxfeld, E. (2005). Cross-Border Hypergamy? Marriage Exchanges in a Transnational Hakka Community in Nicole Constable (ed.). Cross-Border Marriages Gender and Mobility in Transnation Asia. Philadelphia: University of Pennsylvania Press.

Pothisita, C. (2004). Sciences and art of qualitative Research. Nakhon Phatom: Institute of Population and Social Research, Mahidol University.

Preedapan, T., \& Ayuwat, D. (2017). Economic security, cross-cultural marriages, security ensuring processes. International journal of Applied Business and Economic Research, 15(10).

Ravenstein, E. G. (1885). The Laws of Migration. Journal of the Statistical Society of London, 48(2), 167-235.

Ruenkaew, P. (1998). Thai Women in Germany: The Case of Marriage Migration as a Tool in Women's Studies. Bangkok: Woman and Youth Project, Thammasat University.

Sassen, S. (2000). Women's Burden: Counter-geographies of Globalization and the Feminization of Survival. Journal of International Affairs, 53, (2), 503-524. 
INTERNATIONAL JOURNAL OF ACADEMIC RESEARCH IN BUSINESS AND SOCIAL SCIENCES

Vol. 10, No. 14, Special Issue: WSTI2018 - Issues and Trends on Education, Science and Technology, 2020, E-ISSN: 2222 -6990 @ 2020 HRMARS

Suzuki, N. (2005). Tripartite Desires: Filipina-Japanese Marriages and Fan tasies of Transnational Traversal. In Nicole Constable (ed.). Cross-Border Marriages Gender and Mobility in Transnation Asia. Philadelphia: University of Pennsylvania Press.

The Population Reference Bureau of Washington. (2014). 2014 World Population Data Sheet. Washington DC: Population Reference Bureau. 